\title{
Effect of Air Pollution from Pedestrian Traffic in an Open Market: A Case Study of Bodija Market, Nigeria
}

\author{
Oluyemisi J. Oladejo ${ }^{1}$, Timothy O. Odeyale ${ }^{2 *}$, Bukola R. Adiamo ${ }^{1}$ \\ ${ }^{1}$ Department of Civil Engineering, University of Ibadan, Ibadan 200284, Nigeria \\ ${ }^{2}$ Department of Architecture, University of Ibadan, Ibadan 200284, Nigeria
}

Corresponding Author Email: dr.odeyale@gmail.com

https://doi.org/10.18280/ijsdp.150718

Received: 11 August 2020

Accepted: 13 October 2020

\section{Keywords:}

air pollution, particulate, PM2.5, open

market, pedestrian traffic, sustainability

\begin{abstract}
Market air quality is very important to the economic lives of the people which is rarely researched, however, market activities particularly pedestrian traffic releases particulates which is detrimental to the health of the users and stakeholders. Thermo scientific MIE pDR1500 particulate was used to monitor the quality of air within the market for eight (8) weeks, air pollutant of concern is PM2.5. Ten (10) sample points were located in the market which covers ten (10) sample points for pedestrian traffic to represent the entire market environment spectrum. The analysis of PM2.5 measured daily during dry and wet season shows a clear seasonal variation of this particular pollutant as elevated concentration was measured during the dry season than the wet season. The assessment of PM2.5 concentration shows exceedances of the standards stated by WHO and NAAQS during the dry season which ranges from $47.9 \mu \mathrm{g} / \mathrm{m}^{3}-231.88 \mu \mathrm{g} / \mathrm{m}^{3}$ in the morning and $65.17 \mu \mathrm{g} / \mathrm{m}^{3}-1806.33 \mu \mathrm{g} / \mathrm{m}^{3}$ in the afternoon. From the findings, pedestrian traffic contributes immensely to air pollution in an open market, with this elevated concentration, prolonged exposure is highly detrimental to health. This study creates awareness to the pedestrians in an open market about air pollution and informs policy changes.
\end{abstract}

\section{INTRODUCTION}

Air quality in the world is a current concern for both developed and developing countries. It is reported that 53 per 100,000 capita global deaths were attributable to ambient air pollution, 3,732,500 deaths average. The data observed show the impact on human health from pollutants such as particulate matter (PM10 and PM2.5), Ozone $\left(\mathrm{O}_{3}\right)$, Nitrogen oxides (NOx) and Sulphur dioxide $\left(\mathrm{SO}_{2}\right)$. It is reported that air pollution in 2012 caused the deaths of around 7 million people worldwide [1]. Air quality refers to the condition of the air within our surrounding that is free of gaseous impurities and pollutants such as smoke, dust and smog [2-4]. The good quality of air can be degraded by the day to day emissions from different air pollution sources especially in the marketplace [4, 5].

Pedestrian traffic in market places involves people moving back and forth by foot for different activities in the market, this causes air pollution, which is often neglected. Air pollution caused by pedestrian traffic is one of the major problems depleting the quality of air within market places and it is a pointer to its overall sustainability and user's well-being [6,7]. Most of our local markets are not well structured, most roads within the markets are also untarred, the back and forth movement of pedestrians, vehicles, truck-pushers etc. in the market contribute to the release of particulates/ dust. Nearly 30 to 40 percent of the population of a Yoruba town is engaged in trade and commerce [8-10]. Apart from the business done in shops and stores on the streets, most of the trading activities take place in town and village markets [11]. Roadside vendors generally spend 8-10 hours on the margins of the road and are continuously exposed to the vehicular emissions as well as fugitive dust [12]. Many market places, shops, business centres are close to roadsides thereby exposing these people to harmful pollutants which may have no serious effects now but in the long term could lead to respiratory diseases and possibly death. Some common air pollutants in marketplaces include; carbon monoxide, nitrogen dioxide, Sulphur dioxide, hydrogen sulphide, volatile organic compounds, ammonia, methane and total suspended particulate. The presence of these pollutants in the air depends on the nature of the activities within the market.

In recent times, studies of air pollution, especially in the urban environment, have focused largely on respirable dust, including seasonal variation and the threat poses to human health [13-15]. Respirable dust pollution which contributes to atmospheric heavy metal load is derived through natural and anthropogenic activities [16, 17].

The respirable fraction is composed of the very fine dust which can reach the lower bronchioles and alveolar regions of the lung, this dust has been implicated to have the potential to carry a high loading of contaminated species such as heavy metals and organic pollutants. Few studies have reported annual mean levels of coarse and fine particles, collective evidence from short- and long-term air monitoring studies across urban Africa and demonstrate that pollution levels often exceed international guidelines [18]. Particulate matter (PM) negative impacts on humans, environment and atmospheric conditions including cloud formation, solar radiation, global warming, visibility and precipitation $[19,20]$. Nigeria is still 
far behind in cut-edge researches on air pollution compared to developed nations of the world. Few works have been done on PM determination and source apportionment in Nigeria [2123]. These reported studies were based mainly on total suspended particles while few on coarse particles, PM10 and fine particles. It has been estimated that a man can live weeks without food and five days without water, but only five minutes without air $[17,24]$. This implies that air is very essential for human existence. Various authors have researched particulate matter; using roads, vehicles and industrial areas as reference points [17, 25-31]. Mafuyai et al. [23] used some method to explain some phenomenons and assert that respirable dust pollution which contributes to atmospheric heavy metal load is derived through natural and anthropogenic activities. Petkova et al. [25] did an overview of published monitoring particulate matter (PM) pollution studies in African cities. The review reveals that, few studies have reported annual mean levels of coarse and fine particles, collective evidence from short- and long-term air monitoring studies across urban Africa demonstrates that pollution levels often exceed international guidelines [32-34]. Manisalidis et al. [15] furthermore, assert that pollution levels may be rising as a result of increased motor vehicle traffic building on already high background concentrations of PM in many locations due to climatic and geographic conditions Biomass burning and industrial activities, often located in cities, further exacerbate levels of PM. Al-Awadhi, conducted a study on air pollution in Kuwait City and measures gaseous $\mathrm{SO}_{2}, \mathrm{NO}$, $\mathrm{NO} 2, \mathrm{H} 2 \mathrm{~S}, \mathrm{O}_{3}, \mathrm{NH}_{3}$ and VOCs, using IVL passive sampler technology [35]. The results of this study reveal that those compounds had low concentrations compared to Kuwait Environment Public Authority standards for residential areas. It was found that nitrogen oxides, benzene and xylene were mostly emitted from motor vehicles; in contrast, industrial sources including oil industries were a major contributor to sulfur dioxide and toluene pollution and concluded that actions should be taken to reduce emission and studies are needed to assess the role of local sources on long term environmental impacts. Thereby giving increasing evidence to suggest that pollution from particulate which is one of the most common pollutants in market places, at levels hitherto considered "safe" is associated with an increased risk of morbidity and mortality (disease and death) from heart disease as well as lung disease. However, most of these researchers focused on industrial areas and traffic emission with little consideration to open market which is also one of the major areas of concern due to the various activities in the market which pollute the air and considering the number of pedestrians in the market, thereby endangering the public health, hence the necessity for this study.

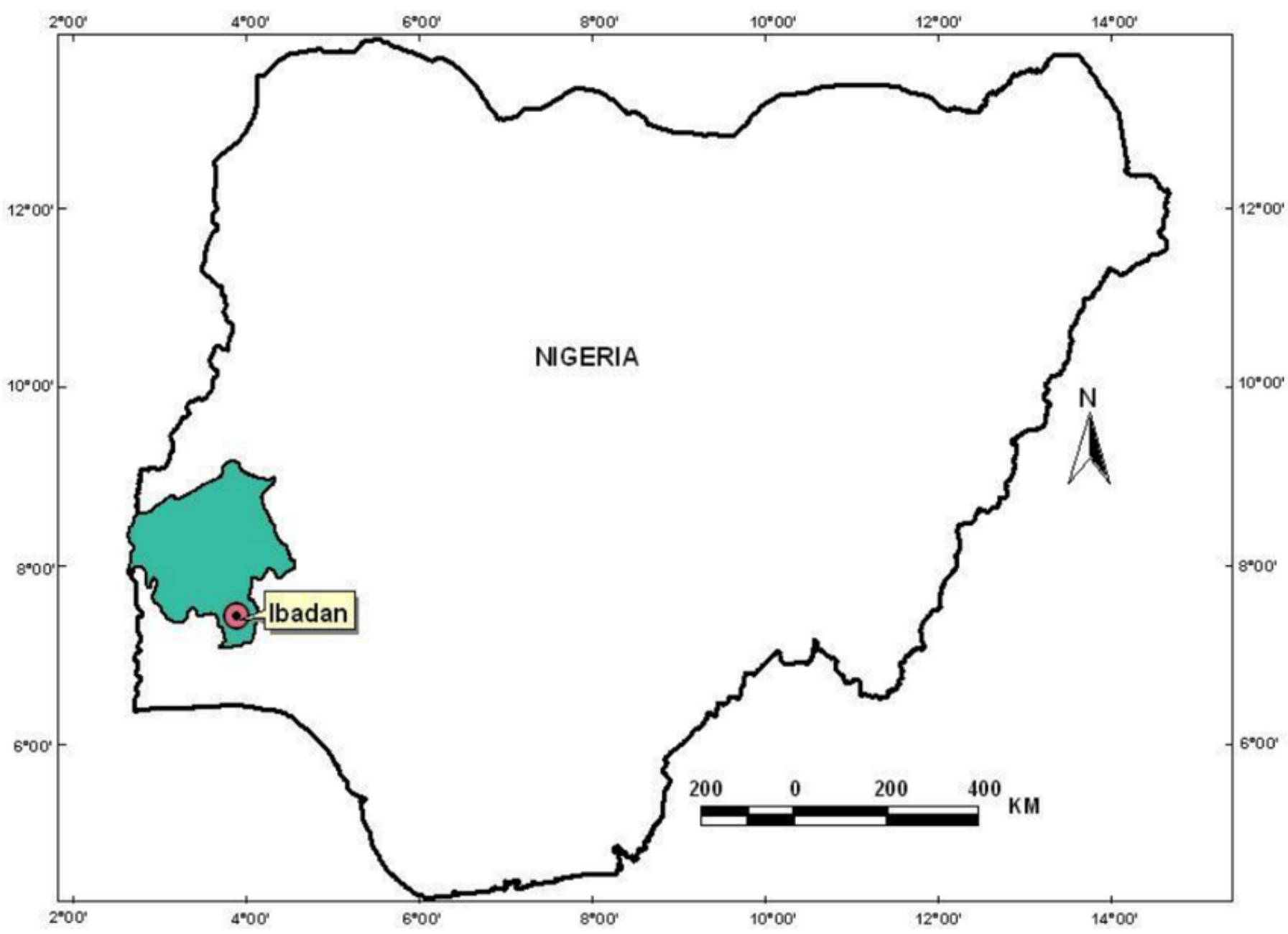

(a) Map of Nigeria showing Oyo State, Nigeria 


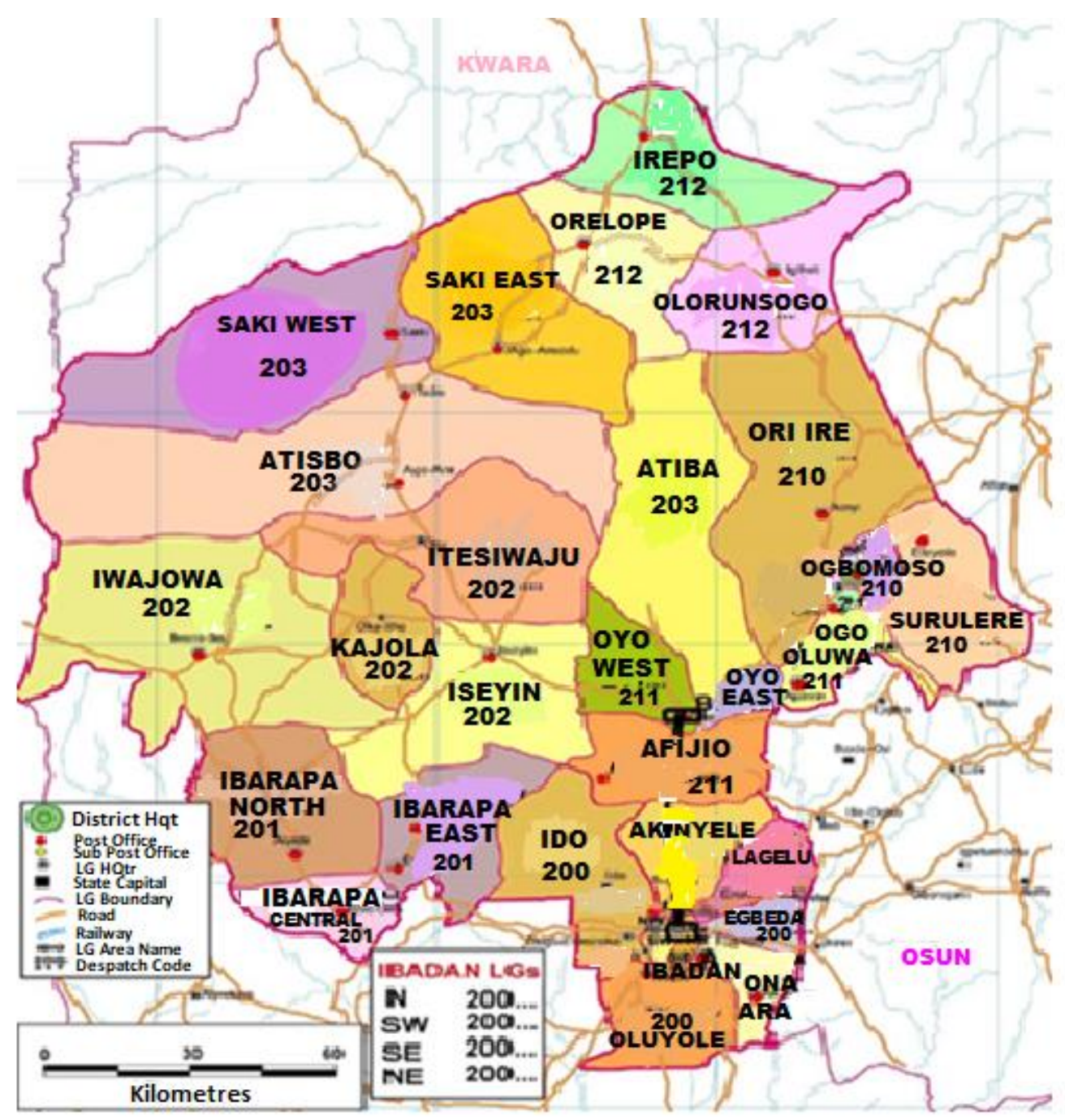

(b) Map showing the study area in Ibadan, Oyo State

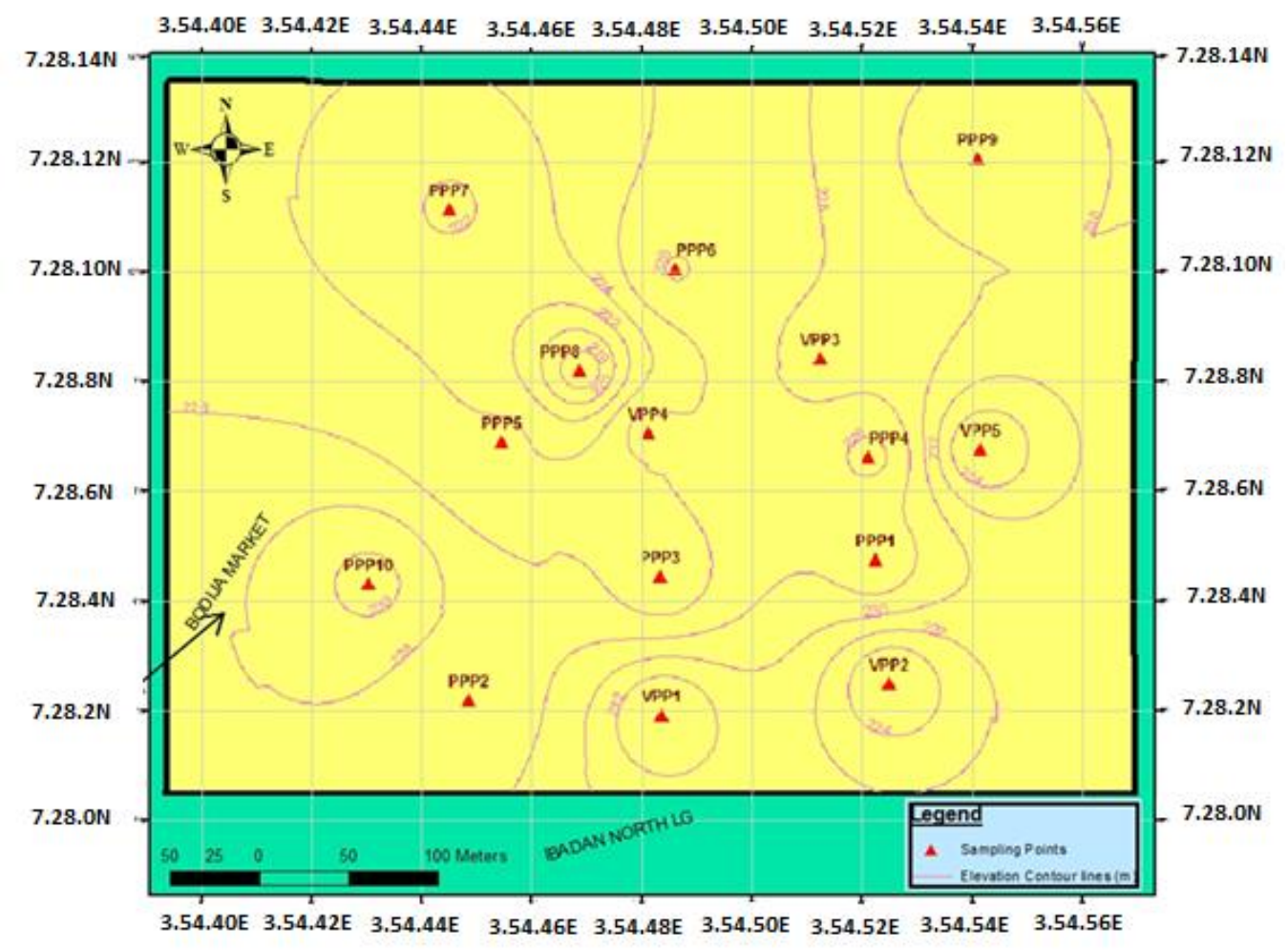

(c) sample points at Bodija

Figure 1. Map of the study area showing the sample points 


\section{STUDY AREA}

A preliminary inventory of all open markets in Ibadan shows that there are numerous open markets in Ibadan namely Oje Market, Ojo Market, Bodija market, Dugbe market, Agbeni market, Aleshinloye market, Oja Oba, to mention a few. Out of all these market, Bodija market was chosen for this study being the biggest and populous market in Ibadan with different activities that makes it a good representative of an open market. Bodija market is predominantly a big farmers market. That is open to the sale of traditional foodstuff and daily needs. The market serves the local and regional need of the people, with marketers bringing foodstuffs from the villages and surrounding farmlands to sell directly to the local people. Bodija market is one of the largest traditional food markets in Ibadan, southwest Nigeria, and it is easily accessible to the local population because of its location in the heartland of Ibadan land and near to the University of Ibadan campus (the oldest university community in Nigeria). Bodija market in Ibadan, Oyo State, and a cosmopolitan city whose population continues to increase daily. The market is situated along the secretariat - U.I road, within the territory of Ibadan North Local Government, which is the most populated of the 11 local governments (see Figure 1). The market is bordered in the North by Agbowo and Orogun, in the south by Bodija estate, while in the West and East are Sango and Bashorun/ Ashi respectively. The location of the market has a lot of advantages. From the viewpoint of proximity, the market is easily accessible to agriculturists, who come from Saki, Oyo, Ogbomoso and the Northern parts of Nigeria. The location is also suitable for easy distribution in and out of the city as it is served by varying network of roads.

10 sample points were taken along the roads and shops restricted to pedestrian activities to represent particulate generation points by pedestrians (see Table 1). These sample locations cover areas of dense to sparse vehicular movement, pedestrian activities, grinding stores, chemical trading, foods etc. These sample points were considered as a representative of the entire market environment and spectrum of activities.

Table 1. Sampling sites characteristics including geographic co-ordinates

\begin{tabular}{ccc}
\hline $\begin{array}{c}\text { Sample } \\
\text { Points }\end{array}$ & Characteristics & Co-ordinates \\
\hline PPP 1 & Mainly Provision & 07.43583N, 003.91402E \\
& stores & Alt: 226.8m \\
PPP 2 & Fruits and other & 07.43571N, 003.91391E \\
& groceries & Alt: $226.6 \mathrm{~m}$ \\
PPP 3 & Vegetables and pepper & 07.43604N, 003.91434 \\
& Alt: 224.5m \\
PPP 4 & Vegetables, pepper, & 07.43589N, 003.91427 \\
& meat & Alt: 225.2m \\
PPP 5 & Mainly yam sellers & 07.43595N, 003.91418E \\
& Alt: 224.2m \\
PPP 6 & little grinding mill & 07.43592N, 003.91421E \\
& Alt: 228.1m \\
PPP 7 & Grinding mill & 07.43551N, 003.91354E \\
& Foodstuffs such as & Alt: 221.8m \\
PPP 8 & rice, beans, melons, & 07.43616N, 003.91314E \\
& garri, etc. & Alt: 216.9m \\
PPP 9 & Abattoir & 07.43457N, 003.91183E \\
& Plastics and other & 07.43573N, 003.91409E \\
PPP10 & household utensils & Alt:230.6m \\
\hline
\end{tabular}

\section{MATERIALS AND METHODS}

\subsection{Sampling}

Preliminary inventory of open markets and closed market in Ibadan clearly shows that Bodija Market is a good representative of traditional food markets in Ibadan being the largest with highest number of pedestrians visiting daily and also comprises numerous pedestrian and vehicular activities while Shoprite is also a good match for closed market (modern mall) which served as a control having almost the same pedestrian and vehicular activities with Bodija Market. Reconnaissance survey shows that the roads patterns and the activities of both pedestrian and vehicles are arranged in such a way that some roads are restricted to pedestrians alone. Hence, five (5) sample points were taken along the roads that have more vehicular activities to represent the particulates generation points by vehicular activities while 10 sample points were taken along the roads and shops restricted to pedestrian activities to represent particulate generation points by pedestrians (see Figures 2 and 3). These sample locations cover areas of dense to sparse vehicular movement, pedestrian activities, grinding stores, chemical trading, foods etc. These sample points were considered as a representative of the entire market environment and spectrum of activities. The control location was Shoprite located at Dugbe which is a closed market but has similar activities with Bodija market. It is located few kilometers away from Bodija market.

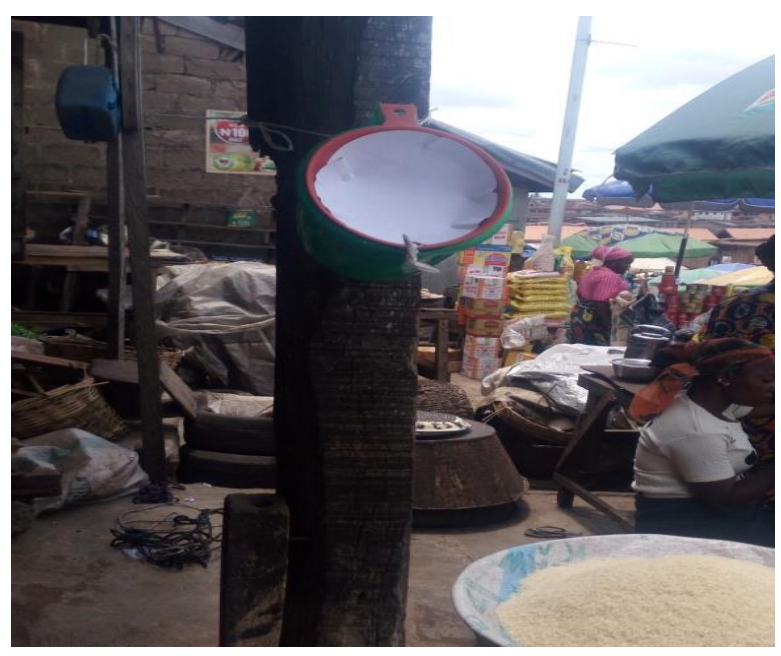

Figure 2. Improvised particulate collector before exposure

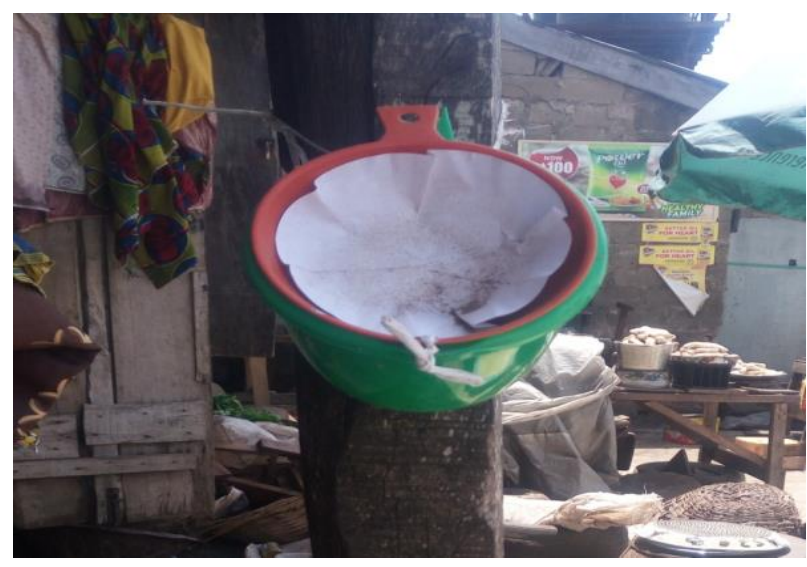

Figure 3. Improvised particulate collector after 2 days of exposure 
Thermo Scientific MIE pDR-1500 particulate meter was to measure the concentration of PM2.5 within the study area. PM2.5 was chosen out of other particle sizes because of its recorded health effect, being the most dangerous respirable particles, causing a different kind of lung diseases. The device used for monitoring is an easy to use equipment that provides fast and accurate measurement of particulate contamination in particles per cubic foot. The device was switched on and then calibrated. It was then placed on a stable platform to ensure the accuracy of the measurement. The measurement was recorded when the readings on the display screen were stable. Readings of PM2.5 was done at each sample point in the market in such a way that three readings were taken at every 2 minutes for 12 minutes in other to get the average readings for that minute to ensure accuracy. The monitoring was carried out, same time at $9 \mathrm{am}$, in the morning and $1 \mathrm{pm}$ in the afternoon corresponding to peak market activities for four (4) weeks during the dry season and four (4) weeks during the wet season.

\section{DISCUSSION}

From Tables 2 and 3, it could be deduced that the concentration of PM2.5 caused by pedestrian activities is higher than the measured control from a closed market.

Table 2. Average weekly morning PM2.5 readings from both vehicular and pedestrian traffic for the dry season

\begin{tabular}{ccccc}
\hline & \multicolumn{4}{c}{$\begin{array}{c}\text { Average weekly concentration of PM2.5 } \\
\text { for dry season }\left(\boldsymbol{\mu g} / \mathbf{m}^{3}\right)\end{array}$} \\
\cline { 2 - 5 } Sample & \multicolumn{4}{c}{ MORNING SESSION } \\
\cline { 2 - 5 } Points & Week & Week & Week & Week \\
& $\mathbf{1}$ & $\mathbf{2}$ & $\mathbf{3}$ & $\mathbf{4}$ \\
\cline { 2 - 5 } & \multicolumn{4}{c}{ Pedestrians } \\
\hline PPP 1 & 52.47 & 51.20 & 53.57 & 52.83 \\
PPP 2 & 54.48 & 56.18 & 57.87 & 57.30 \\
PPP 3 & 51.83 & 55.42 & 53.83 & 55.68 \\
PPP 4 & 49.62 & 59.78 & 55.48 & 58.37 \\
PPP 5 & 72.63 & 203.52 & 71.97 & 61.78 \\
PPP 6 & 163.68 & 72.58 & 181.02 & 177.62 \\
PPP 7 & 219.20 & 231.88 & 230.47 & 227.00 \\
PPP 8 & 190.73 & 167.28 & 155.83 & 141.47 \\
PPP 9 & 55.10 & 60.60 & 52.20 & 51.70 \\
PPP10 & 52.63 & 54.50 & 50.03 & 47.90 \\
\hline
\end{tabular}

Table 3. Average weekly afternoon PM2.5 readings from both vehicular and pedestrian traffic for dry season

\begin{tabular}{ccccc}
\hline & \multicolumn{4}{c}{$\begin{array}{c}\text { Average weekly concentration of PM2.5 for } \\
\text { dry season }\left(\boldsymbol{\mu g} / \mathbf{m}^{3}\right)\end{array}$} \\
\cline { 2 - 5 } Sample & \multicolumn{4}{c}{ AFTERNOON SESSION } \\
\cline { 2 - 5 } Points & Week 1 & Week 2 & Week 3 & Week \\
& \multicolumn{4}{c}{ Pedestrians } \\
\cline { 2 - 5 } & 78.73 & 75.10 & 72.83 & 77.20 \\
\hline PPP 1 & 74.42 & 74.85 & 77.23 & 73.10 \\
PPP 2 & 65.17 & 71.17 & 71.95 & 72.80 \\
PPP 3 & 75.52 & 77.65 & 71.83 & 71.48 \\
PPP 4 & 618.35 & 655.43 & 632.80 & 563.67 \\
PPP 5 & 1645.00 & 1806.33 & 1794.83 & 1779.93 \\
PPP 6 & 1539.67 & 1751.83 & 1704.23 & 1411.40 \\
PPP 7 & 15.95 & 537.85 \\
PPP 8 & 465.95 & 527.12 & 569.55 & 75.40 \\
PPP 9 & 99.267 & 88.20 & 78.77 & 73.15 \\
PPP10 & 110.25 & 87.62 & 68.82 & \\
\hline
\end{tabular}

The concentration varied from $52.47 \mu \mathrm{g} / \mathrm{m}^{3}-219.20 \mu \mathrm{g} / \mathrm{m}^{3}$ in the first week of morning monitoring in the dry season, $51.20 \mu \mathrm{g} / \mathrm{m}^{3}-231.88 \mu \mathrm{g} / \mathrm{m}^{3}$ for the second week of monitoring, $50.03 \mu \mathrm{g} / \mathrm{m}^{3}-230.47 \mu \mathrm{g} / \mathrm{m}^{3}$ and $47.90 \mu \mathrm{g} / \mathrm{m}^{3}-$ $227.0 \mu \mathrm{g} / \mathrm{m}^{3}$ for third and fourth week morning monitoring respectively while the concentration varies in the afternoon from $65.17 \mu \mathrm{g} / \mathrm{m}^{3}-1539.67 \mu \mathrm{g} / \mathrm{m}^{3}, 71.17 \mu \mathrm{g} / \mathrm{m}^{3}-1806.33$ $\mu \mathrm{g} / \mathrm{m}^{3}, 71.83 \mu \mathrm{g} / \mathrm{m}^{3}-1794.83 \mu \mathrm{g} / \mathrm{m}^{3}, 71.48 \mu \mathrm{g} / \mathrm{m}^{3}-1779.93$ $\mu \mathrm{g} / \mathrm{m}^{3}$ for the first, second, third and fourth week respectively. World Health Organization (WHO) recommends $25 \mu \mathrm{g} / \mathrm{m}^{3}$ while the National Ambient Air Quality Standard (NAAQS) recommends $35 \mu \mathrm{g} / \mathrm{m}^{3}$ as the maximum permissible limit that ensures $95 \%$ safety from lung diseases.

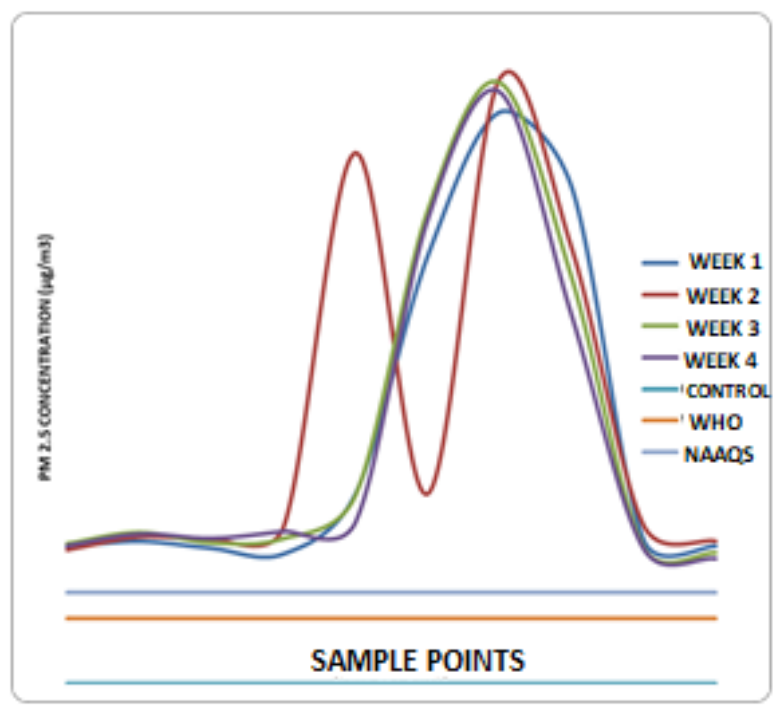

Figure 4. The trend of PM2.5 pollutions by pedestrians in the morning during the dry season

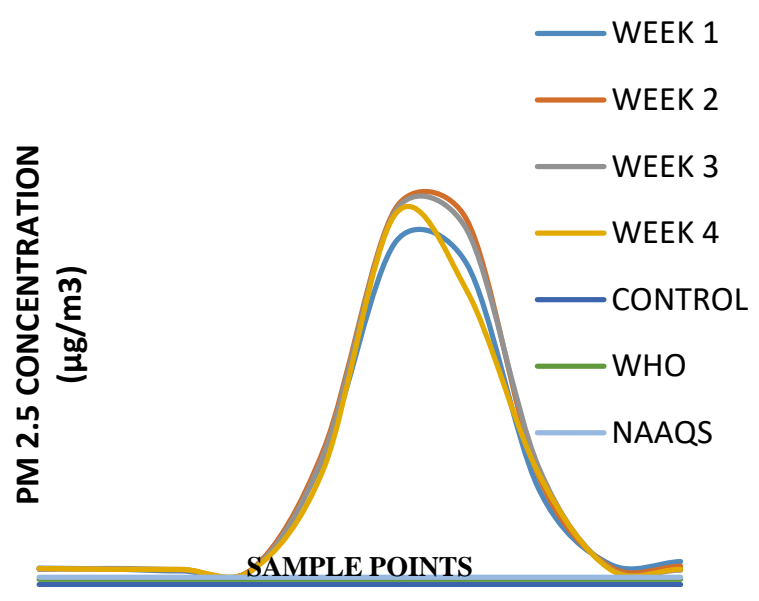

Figure 5. The trend of PM2.5 pollutions by pedestrians in the afternoon during the dry season

However, none of these sample points within the market meets up with the standards either in the morning or afternoon. Figures 4 and 5 give the trend of PM2.5 pollutions by pedestrian traffic within the study area for the four weeks monitoring as compared with the control for the study, WHO, and NAAQS standards. It is evident from the graph that the concentration of PM2.5 during the dry season is very high against the standards with an elevated concentration in the afternoon. The elevated concentration of PM2.5 at the study 
area is due to the activities of the pedestrians within the market which causes the release of particulate into the atmosphere.

A high concentration of particulates in the afternoon is due to an increase in market activities in the afternoon than in the morning. Also, the season affects the increase in the concentration of PM2.5 in the air as there is no enough moisture content in the air to absorb the particulates released into the atmosphere by these pedestrians. PM2.5 which is highly respirable of all the particulate matter and can get deep into the lung and kidney, thereby causing a lung infection. However most of the market dwellers are negligence of its impact on their health, hence they do not care to use protective. Air pollution in African cities that despite the health risk air pollution presents, air quality programs, particularly in SubSahara Africa, have been stalled or discontinued in recent years, hence the increase in depletion of air quality and less awareness [36-38].

Table 4. Average weekly morning PM2.5 readings from both vehicular and pedestrian traffic for the wet season

\begin{tabular}{ccccc}
\hline & \multicolumn{3}{c}{$\begin{array}{c}\text { Average weekly concentration of PM2.5 } \\
\text { for wet season }\left(\boldsymbol{\mu g} / \mathbf{m}^{\mathbf{3}}\right)\end{array}$} \\
\cline { 2 - 5 } Sample & \multicolumn{4}{c}{ MORNING SESSION } \\
\cline { 2 - 5 } Points & Week & Week & Week & Week \\
& $\mathbf{1}$ & $\mathbf{2}$ & $\mathbf{3}$ & $\mathbf{4}$ \\
\cline { 2 - 5 } & \multicolumn{4}{c}{ Pedestrians } \\
\hline PPP 1 & 18.70 & 13.42 & 12.45 & 11.58 \\
PPP 2 & 17.68 & 13.07 & 11.83 & 12.28 \\
PPP 3 & 15.33 & 15.27 & 12.42 & 12.63 \\
PPP 4 & 14.35 & 13.73 & 13.25 & 10.30 \\
PPP 5 & 24.03 & 20.18 & 18.85 & 13.30 \\
PPP 6 & 22.20 & 20.23 & 20.28 & 15.50 \\
PPP 7 & 31.18 & 27.77 & 27.57 & 24.48 \\
PPP 8 & 28.63 & 22.93 & 21.32 & 17.97 \\
PPP 9 & 22.60 & 18.92 & 17.43 & 14.47 \\
PPP10 & 18.98 & 16.23 & 12.62 & 10.97 \\
\hline
\end{tabular}

Table 5. Average weekly afternoon PM2.5 readings from both vehicular and pedestrian traffic for the wet season

\begin{tabular}{ccccc}
\hline & \multicolumn{4}{c}{$\begin{array}{c}\text { Average weekly concentration of PM2.5 } \\
\text { for wet season }\left(\boldsymbol{\mu g} / \mathbf{m}^{\mathbf{3}}\right)\end{array}$} \\
\cline { 2 - 5 } Sample & \multicolumn{4}{c}{ MORNING SESSION } \\
\cline { 2 - 5 } Points & Week & Week & Week & Week \\
& $\mathbf{1}$ & $\mathbf{2}$ & $\mathbf{3}$ & $\mathbf{4}$ \\
\cline { 2 - 5 } & \multicolumn{4}{c}{ Pedestrians } \\
\hline PPP 1 & 25.68 & 23.65 & 23.70 & 20.33 \\
PPP 2 & 24.27 & 23.63 & 20.37 & 18.85 \\
PPP 3 & 26.90 & 27.67 & 23.57 & 22.30 \\
PPP 4 & 23.18 & 27.20 & 24.62 & 18.28 \\
PPP 5 & 57.87 & 41.67 & 35.55 & 26.93 \\
PPP 6 & 61.05 & 44.68 & 37.67 & 21.38 \\
PPP 7 & 750.57 & 589.03 & 567.63 & 222.45 \\
PPP 8 & 113.85 & 94.53 & 102.53 & 51.37 \\
PPP 9 & 56.47 & 32.13 & 28.17 & 22.52 \\
PPP10 & 29.42 & 22.83 & 18.50 & 17.17 \\
\hline
\end{tabular}

The mean concentration of PM2.5 by pedestrian traffic during wet season compared with standard as presented in Tables 4 and 5 above show that some of the locations have a concentration within WHO and NAAQS standard in the morning ranging from $14.35 \mu \mathrm{g} / \mathrm{m}^{3}-31.18 \mu \mathrm{g} / \mathrm{m}^{3}, 13.07$ $\mu \mathrm{g} / \mathrm{m}^{3}-27.77 \mu \mathrm{g} / \mathrm{m}^{3}, 11.83 \mu \mathrm{g} / \mathrm{m}^{3}-27.52 \mu \mathrm{g} / \mathrm{m}^{3}, 10.30 \mu \mathrm{g} / \mathrm{m}^{3}-$
$24.48 \mu \mathrm{g} / \mathrm{m}^{3}$ for the first week, second, third and fourth week respectively while the concentration slightly increases in the afternoon ranging from $24.27 \mu \mathrm{g} / \mathrm{m}^{3}-750.57 \mu \mathrm{g} / \mathrm{m}^{3}, 22.83$ $\mu \mathrm{g} / \mathrm{m}^{3}-589.03 \mu \mathrm{g} / \mathrm{m}^{3}, 18.50 \mu \mathrm{g} / \mathrm{m}^{3}-567.63 \mu \mathrm{g} / \mathrm{m}^{3}, 17.17$ $\mu \mathrm{g} / \mathrm{m}^{3}-222.45 \mu \mathrm{g} / \mathrm{m}^{3}$ for the first, second, third, and fourth week respectively during afternoon monitoring for the wet season. Some of the sample points do not fall within WHO and NAAQS, some falls within the WHO standard but above NAAQS standard, while the control experiment falls within both standard. PPP7 has elevated value ranging from $222.45 \mu \mathrm{g} / \mathrm{m}^{3}-750.57 \mu \mathrm{g} / \mathrm{m}^{3}$. The concentration of PM2.5 in wet season ranges from $10.30 \mu \mathrm{g} / \mathrm{m}^{3}-32.18 \mu \mathrm{g} / \mathrm{m}^{3}$ in the morning and $17.17 \mu \mathrm{g} / \mathrm{m}^{3}-750.57 \mu \mathrm{g} / \mathrm{m}^{3}$ in the afternoon. Figures 6 and 7 below give the trend of particulate pollution by pedestrian traffic during the wet season for morning and afternoon periods, it is evident from the graph that the reduction in the concentration of PM2.5 is inward wet season, the first week of monitoring has the highest concentration being the inception of raining season i.e onset of the raining season while the concentration reduces towards the wet season. The reduction in the level of PM2.5 during this period is because there is enough moisture in the atmosphere to absorb these particulates. Also, the untarred floor will have high moisture content hence, little or no particulate will be generated by the back and forth movement of the market dwellers. However, the foodstuff sellers and millers are at high risk of inhaling PM2.5 (respirable dust) during this period while grinding, dusting beans, garri, melon, etc without using protective at least a nose mask. Aybek and Selcuket 2007, reported that respirable dust is a useful indicator of the level and distributor of heavy metals contamination in the atmosphere which may affect air quality with its deleterious environmental consequences including harm to human life, this shows how dangerous PM2.5 could be which is at high concentration in the market.

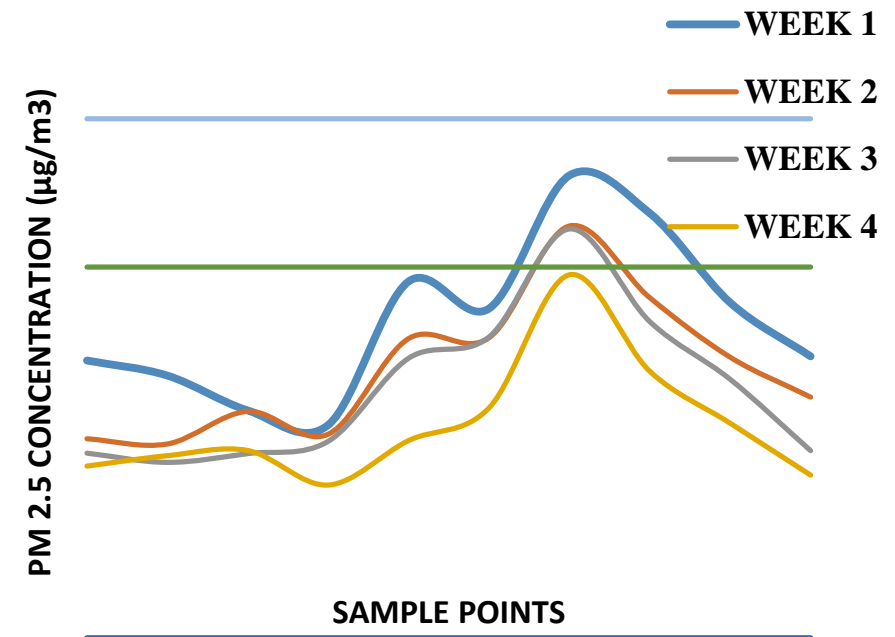

Figure 6. The trend of PM2.5 pollutions by pedestrians in the morning during the wet season

The experimental data reveal that the concentration of PM2.5 is higher in the dry season than a wet season at different sections of the market, this complies with the research made by Gobo et al after assessing the air quality and noise around Okrika Communities, Rivers State. 


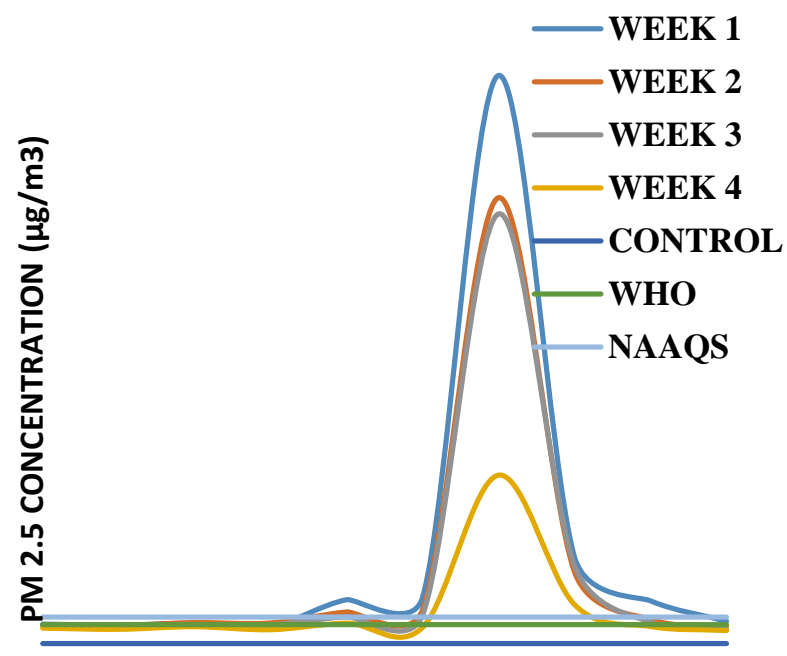

SAMPLE POINTS

Figure 7. The trend of PM2.5 pollutions by pedestrians in the afternoon during the wet season

\section{CONCLUSIONS AND RECOMMENDATIONS}

In the present study, an extensive evaluation of air pollution from pedestrian traffic in an open market was conducted using Bodija market as a case study. Air quality monitoring device (PM meter) was used to monitor the concentration of PM2.5 (which is the most dangerous size of particulate) from pedestrian traffic during the dry and wet season. The assessment of PM2.5 concentration caused by pedestrian traffic shows exceedances of the standards stated by WHO and NAAQS during dry season whereas the concentration falls within the standard for the wet season except for some areas of the market especially grinding mill section which violated the $25 \mu \mathrm{g} / \mathrm{m}^{3}$ by WHO and NAAQS $35 \mu \mathrm{g} / \mathrm{m}^{3}$ irrespective of the season. With these elevated concentrations of PM2.5 in the market, it is evident from the survey that air pollution affects the health of pedestrians in the market. Most of them experience sneezing, irritation of eyes, nose and throat, headache etc. which are the most common symptoms related to air pollution. It is important to consider ways and how to reduce air pollution. Based on the analysis and findings of this study that the pollution in wet season is less than that in dry season, we can reduce air pollution by increasing air humidity through sprinkling water in dry season. It is also suggested that the government should endeavor to tar the roads within the market so as to reduce the level of particulate released into the air by pedestrians and vehicular traffic which is more during dry season. And further future study would be carried out to analyze the PM2.5 concentrations after the improvement measures. It is also important to consider ways and how to prevent air pollution in open markets, such as encouraging the market users and pedestrians to wear masks in open markets, and different types of shops, such as the foodstuff sellers, should be scattered to reduce the concentration of particulates into the atmosphere. In addition, grinding mill section contributes to a larger percentage of particulate generation in the market hence it should be cited is a more spacious environment and some kilometers away from the market where people converge every day. Prolonged exposure without a remedy may affect their internal organ especially those at the grinding mill section and foodstuff sellers. Hence, attention is needed in this sector of the economy as it is an important sector that cannot be overlooked.

\section{REFERENCES}

[1] Quansah, R., Semple, S., Ochieng, C.A., Juvekar, S., Armah, F.A., Luginaah. I., Emina, J. (2017). Effectiveness of interventions to, reduce household air pollution and/or improve health in homes using solid fuel in low-and-middle-income countries: A systematic review and meta-analysis. Environment International, 103: 73-90. https://doi.org/10.1016/j.envint.2017.03.010

[2] Ezzati, M., Utzinger, J., Cairncross, S., Cohen, A.J., Singer, B.H. (2005). Environmental risks in the developing world: Exposure indicators for evaluating interventions, programmes, and policies. Journal of Epidemiology Community Health, 59(1): 15-22. https://doi.org/10.1136/jech.2003.019471

[3] Mannucci, P.M., Harari, S., Martinelli, I., Franchini, M. (2015). Effects on the health of air pollution: A narrative review. International and Emergency Medicien, 10: 657662. https://doi.org/10.1007/s11739-015-1276-7

[4] Tuomisto, J.T., Andrew, W., John, S.E., Marko, T. (2008). Uncertainty in mortality response to airborne fine particulate matter: Combining European air pollution experts. Reliability Engineering \& System Safety, 93(5): 732-744. https://doi.org/10.1016/j.ress.2007.03.002

[5] Burroughs, P.M.S., Rollins, A. (2017). Environmental exposures and cardiovascular disease: A challenge for health and development in low- and middle-income countries. Cardiology Clinics, 35(1): 71-86. https://doi.org/10.1016/j.ccl.2016.09.001

[6] World Health Organization (WHO). Air Quality Guidelines for Europe. WHO Regional Publications, European Series No. 91, WHO Regional Office for Europe, Copenhagen, WHO. Burden of Disease from Ambient Air Pollution for 2012. http://www.who.int/phe/health_topics/outdoorair/databa ses/AAP_BoD_results_March2014.pdf accessed on accessed on Jan. 31, 2017.

[7] WHO. (2014). WHO 7 Million Premature Deaths Annually Linked to Air Pollution. http://www.who.int/mediacentre/news/releases/2014/air -pollution/en/, accessed on May 15, 2019.

[8] World Health Organization (WHO). (2005). Air Quality Guidelines for Particulate Matter, Ozone, Nitrogen dioxide and Sulphur dioxide. Global update summary of risk assessment WHO/SDE/PHE/OEH/06.02. http://www.euro.who.int/Document/E87950.pdf, accessed on Jul. 7, 2019.

[9] Zagha, O., Nwaogazie, I.L. (2015). Roadside air pollution assessment in Port-Harcourt, Nigeria. Standard Scientific Research and Essays, 3(3): 066-074.

[10] Piqueras, P., Vizenor, A. (2016). The rapidly growing death toll attributed to air pollution: A global responsibility. Policy Brief for GSDR, pp. 1-4.

[11] Odeyale, T.O. (2020) Actor-network, conflict and the commodification of planning: role of traditional food markets in shaping the built environment. Habitat International, 104: 102255. https://doi.org/10.1016/j.habitatint.2020.102255

[12] Tilt, B. (2019). China's air pollution crisis: Science and policy perspectives. Environmental Science \& Policy, 92: 
275-280. https://doi.org/10.1016/j.envsci.2018.11.020

[13] Plaia, A., Ruggieri, M. (2017). Air quality indices: A review. Reviews in Environmental Science and Bio/Technology, 10 : 165-179. https://doi.org/10.1007/s11157-010-9227-2

[14] Lazor, P., Tomas, J., Toth, T., Toth, J., Ceryova, S. (2012). Monitoring of air pollution and atmospheric deposition of heavy metals by analysis of honey. Journal of Microbiology, Biotechnology and Food Sciences, 1(4): $522-533$

[15] Manisalidis, I., Stavropoulou, E., Stavropoulos, A., Bezirtzoglou, E. (2020). Environmental and health impacts of air pollution: A review. Frontiers in Public Health. https://doi.org/10.3389/fpubh.2020.00014

[16] Schwela, D. (2000). Air pollution and health in urban areas. Reviews on Environmental Health, 15(1-2): 13-42. https://doi.org/10.1515/reveh.2000.15.1-2.13

[17] Lelieveld, J., Evans, J.S., Fnais, M., Giannadaki, D. Pozzer, A. (2015). The contribution of outdoor air pollution sources to premature mortality on a global scale. Nature, 525: 367-371. https://doi.org/10.1038/nature15371

[18] Liu, Y., Lee, K., Perez-Padilla, R., Hudson, N.L., Mannino, D.M. (2008). Outdoor and indoor air pollution and COPD-related diseases in high- and low-income countries. Int. J. Tuberc. Lung. Dis., 12(2): 115-127.

[19] Balogun, F.A. (2011). Management of traditional markets in Ibadan, Nigeria: A focus on Oja'ba and Oje markets. Conference: Shape and be Shaped: The Future Dynamics of Regional Development, United Kingdom.

[20] Filani, M.O. (1994). Ibadan Region. Rex Charles Publication, Ibadan, p.169.

[21] Odeyale, T.O., Omole, F.K., Sodagar, B., Temple, N., O'Coill, C. (2012). Traditional food markets, power relations and waste management: A qualitative study. WIT Transaction on Ecology and the Environment, 163: 37-47. https://doi.org/10.2495/WM120041

[22] Mani, P.A., Swamy, A.V., Hema, K.R. (2013). Studies on the transport related pollutants in the ambient atmosphere and their health impacts on the roadside vendors of the Indian city. European Chemical Bulletin 2(1): 28-37. http://dx.doi.org/10.17628/ecb.2013.2.2837

[23] Mafuyai, G.M., Eneji, I.S. Sha'Ato, R. (2014). Concentration of heavy metals in respirable dust in Jos Metropolitan area, Nigeria. Open Journal of Air Pollution, 3(1): 10-19. http://dx.doi.org/10.4236/ojap.2014.31002

[24] Shah, J., Nagpa, J.T., Brnadon, C. (2006). Urban Air Quality Management Strategy in Asia-Guide Book. The World Bank, USA, 17-21. https://doi.org/10.1596/08213-4032-8

[25] Petkova, E.P., Darby, W., Jack, N., Volavka-Close, H., Patrick, L.K. (2013). Particulate matter pollution in African cities. Air Quality Atmospheric Health, 6: 603614. https://doi.org/10.1007/s11869-013-0199-6

[26] Taiwo, A.M., Beddows, D.C.S., Shi, Z., Harrison, R.M. (2014). Mass and number size distributions of particulate matter components: Comparison of an industrial site and an urban background site. Science Total Environment.
475:

29-38.

https://doi.org/10.1016/j.scitotenv.2013.12.076

[27] Pope, C.A., Dockery, D.W. (2006). Health effects of fine particulate air pollution: lines that connect. Journal of the Air \& Waste Management Association, 56(6): 709-742. http://dx.doi.org/10.1080/10473289.2006.10464485

[28] Owoade, O.K., Fawole, O.G., Olise, F.S., Ogundele, L.T., Olaniyi, H.B., Almeida, M.S., Ho M.D., Hopke P.K. (2013). Characterization and source identification of airborne particulate loadings at receptor site-classes of Lagos mega-city, Nigeria. Journal of the Air \& Waste Management Association, 63(9): 1026-1029. https://doi.org/10.1080/10962247.2013.793627

[29] Efe, S.I., Efe, A.T. (2008). Spatial distribution of particulate matter (PM10) in Warri metropolis, Nigeria. The Environ, 28: 385-394. https://doi.org/10.1007/s10669-007-9154-0

[30] Koku, C.A., Osuntogun, B.A. (2007). Environmental impacts of road transportation in the Southwestern States of Nigeria. Journal of Applied Sciences, 7(16): 25362360. https://doi.org/10.3923/jas.2007.2356.2360

[31] Rao, M.N., Rao, H.V.N. (1989). Air Pollution. Data McGraw-Hill Publishing Company Ltd., New Delhi, pp. $10-25$.

[32] Nwankwoala, H.O., Obioha, S.C. (2013). Preliminary assessment of air and sound quality in Ariaria market, aba, southeastern Nigeria. Journal of Engineering and Technology Research, 2(4): 18-26.

[33] Taiwo, A.M., Arowolo, T.A., Abdullahi, K.L., Taiwo O.T. (2015). Particulate matter pollution in Nigeria: A review. Proceedings of the 14th International Conference on Environmental Science and Technology Rhodes, Greece.

[34] Kim, K.H., Ehsanul, K., Shamin, K. (2015). A review on the human health impact of airborne particulate matter. Environment International, 74: 136-143. http://dx.doi.org/10.1016/j.envint.2014.10.005

[35] Al-Awadhi, J.M. (2014). Measurement of air pollution in Kuwait city using passive samplers. Atmospheric and Climate $\quad$ Sciences, 4(2): 253-271. http://dx.doi.org/10.4236/acs.2014.42028

[36] Offor, I.F., Gilbert, U., Adie, G., REE, A. (2016). Review of particulate matter and elemental composition of aerosols at selected locations in Nigeria from 1985-2015. Journal of Health \& Pollution, 6(10): 1-18. https://doi.org/10.5696/2156-9614-6-10.1

[37] Aybek, A., Selcuk, A. (2007). Dust exposures in tractor and combine operations in eastern Mediterranean, Turkey. Journal of Environmental Biology, 28(4): 839844.

[38] Gobo, A.E., Ideriah, T.J.K., Francis, T.E., Stanley, H.O. (2012). Assessment of air quality and noise around Okrika communities, Rivers State, Nigeria. Journal of Applied Science and Environmental Management, 16(1): $75-83$.

\section{NOMENCLATURE}

PM2.5 Particulate Matter 